\title{
Nurses in advanced roles: a review of acceptability in Portugal ${ }^{1}$
}

\author{
James Buchan² \\ Marta Temido ${ }^{3}$ \\ Ines Fronteira ${ }^{3}$ \\ Luis Lapão ${ }^{3}$ \\ Gilles Dussault ${ }^{3}$
}

Objective: This paper focuses on the policy context for the deployment of nurses in advanced roles, with particular reference to Portugal. The health sector in Portugal, as in all countries, is labour intensive, and the scope to utilise nurses in more advanced roles is currently being debated. Methods: Mixed methods were used: an analysis of international data on the nursing workforce; an analysis of documents and media articles; interviews with key-informants; an online survey of managers, and a technical workshop with key-informants. Conclusions: The limited evidence base on nurses in advanced roles in Portugal is a constraint on progress, but it is not an excuse for inaction. Further research in Portugal on health professionals in innovative roles would assist in informing policy direction. There is the need to move forward with a fully informed policy dialogue, taking account of the current political, economic and health service realities of Portugal.

Descriptors: Nursing; Health Care Reform; Health Manpower; Nursing Staff; Portugal.

\footnotetext{
${ }^{1}$ Supported by World Health Organization, European Region Office.

2 PhD, Professor, School of Health Sciences, Queen Margaret University, UK.

${ }^{3}$ PhD, Professor, Instituto de Higiene e Medicina Tropical, Lisbon, Portugal, Centro Colaborador da OMS para Políticas e Planejamento da Força de Trabalho em Saúde.
} 


\section{Enfermeiros em funções avançadas: uma análise da aceitação em Portugal}

Objetivo: este artigo foca o contexto político da implementação de competências avançadas em enfermagem, com ênfase no caso português. O setor da saúde em Portugal, assim como em outros países, usa mão de obra intensa, e a prática de enfermeiros com competências avançadas está atualmente em debate. Métodos: abordagem de métodos mistos com análise de dados internacionais sobre a mão de obra em enfermagem, documentos e notícias na mídia, entrevistas com informantes-chave, questionário online e um workshop técnico com informantes-chave. Conclusões: existe base de evidência limitada sobre enfermeiros com funções avançadas em Portugal, o que é um entrave ao progresso, mas não uma desculpa para a inércia. Mais estudos conduzidos em Portugal, abordando funções inovadoras para profissionais da saúde, ajudariam a informar e direcionar políticas na área. É necessário avançar para informar, de forma plena, o diálogo político, levando em consideração a realidade atual em termos políticos, econômicos e do sistema de saúde em Portugal.

Descritores: Enfermagem; Reforma dos Serviços de Saúde; Recursos Humanos em Saúde; Recursos Humanos de Enfermagem; Portugal.

\section{Las enfermeras de competencias avanzadas: una revisión de aceptación en Portugal}

Objetivo: Este estudio se focaliza en el contexto político del desarrollo de competencias avanzadas de enfermería, con énfasis en el caso portugués. El sector de la salud en Portugal, como en todos los países, es intensivo en mano de obra, y la posibilidad de utilizar enfermeros en funciones más avanzadas está actualmente en debate. Métodos: Fue utilizado una aproximación mixta: análisis de datos internacionales sobre la fuerza de trabajo de enfermería; análisis de documentos y noticias; entrevistas con informadores clave; un cuestionario online y una oficina técnica con informadores clave. Conclusiones: La limitada base de evidencia sobre la extensión de competencias de los enfermeros en Portugal es un obstáculo para el progreso pero no es una excusa para la inacción. Investigación adicional sobre profesionales de la salud en papeles innovadores podría ayudar a informar y direccionar la decisión política. Es necesario avanzar con un diálogo político plenamente informado, considerando la realidad político económica actual y el sistema de servicios de salud en Portugal.

Descriptores: Enfermería; Reforma de la Atención de Salud; Recursos Humanos en Salud; Personal de Enfermería; Portugal.

\section{Introduction}

This paper draws from work commissioned by the World Health Organisation, European Region and focuses on the policy context for the deployment of nurses in advanced roles, with particular reference to Portugal.

Portugal initiated a phase of health sector reform of its National Health Service in the earlier part of this decade. Human resources issues were identified both as a focus for necessary reform, and as one area for potential improvement in health care delivery and health system effectiveness ${ }^{(1)}$. The health sector in Portugal, as in all countries, is labour intensive, and the scope to utilise nurses and other non medical health professionals in more advanced roles was one of the issues that was identified during the reform process. Portugal is also one of several European countries currently facing a severe economic crisis which has impacted on public sector funding, employment and health care delivery ${ }^{(2)}$. This has both delayed implementation of some of the reform priorities, and raised the need for more urgent focus on methods of improving health care productivity and effectiveness.

In Portugal, the composition of the health workforce has been described as an inefficient combination of resources that may lead to less than optimal productivity, and with access to certain services may be limited as a consequence $^{(3)}$. Various stakeholders have advocated for the revision of the composition of the health workforce and of the scope of practice of professions such as 
nursing, as a measure aimed at improving efficiency in the delivery of services ${ }^{(4-6)}$. One factor that have influenced these stakeholders is that Portugal has one of the lowest nurse to population and to physician ratios in develop countries, and one of the highest physician to population ratios. One argument in support of expanded scopes of practice for nurses in Portugal is that there are many successful international experiences that show that this can be done without negative effects on the quality of services or the safety of users ${ }^{(7-8)}$.

It is within this policy process of health sector cost containment, and ongoing debate about the respective roles of different health professionals in Portugal that the paper examines the scope and potential for using nurses in advanced roles in Portugal. The focus of this report is nurses working in advanced roles/ advanced practice. The "advanced practice nurse" is an umbrella term that that covers a number of nursing roles, the two main types being the nurse practitioner and the nurse specialist (sometimes referred to as clinical nurse specialist). In some countries advanced practice roles are registerable whilst in others the roles are not identified separately on the professional register ${ }^{(9)}$. One key factor in the role of advanced practice is the extent to which the nurse has the authority to legally prescribe drugs. Legislation to enable nurse prescribing is being implemented in a growing range of countries.

Whilst nurses in advanced roles were implemented initially in North America, their use or potential is now observed in a range of countries in most regions of the world. An international study in 2010 reported that nurse practitioner/advanced practice education was available in 23 of 32 countries surveyed(10). There is a range of drivers that can provide the impetus for developing and introducing nurses in advanced roles, including skill shortages, the need to make more cost effective use of skills, the introduction of new services and technologies and changes in regulations and legislative reform ${ }^{(7-8)}$.

A review of the international evidence base on nurses in advanced roles does highlight that there is a growing body of evidence that examines the effectiveness of nurses developing their scope of practice into advanced roles $^{(7-8)}$. Whilst much of the initial evidence emerged from research in North America, the UK and Australia, there has been a broadening out of the evidence base in recent years reflecting the increasing number of countries that are now supporting the use of nurses in advanced roles. The most robust evidence is in the form of systematic reviews and meta-analysis, of which there are relatively few examples ${ }^{(11)}$, but there are also a growing number of randomised controlled trials $\left(R C T^{\prime} s\right)^{(12-13)}$ and some economic evaluations ${ }^{(14)}$. Differences in health systems contexts, current role delineations, data availability and evaluation methods constrain the development of general conclusions from the available international evidence base on the evaluation of advanced practice roles in nursing(7-8)

\section{Methods}

In order to meet the objectives of the analysis, a multipronged research strategy was developed, and five main elements are described in this paper:

- An analysis of international data on the nursing workforce to "map" the nursing workforce profile of Portugal in the broader international context;

- An analysis of recent official, scientific and professional documents, reports and media articles published in Portugal to provide specific country context;

- Interviews with key-informants in Portugal;

- An online survey of opinions of managers of primary care level services in Portugal;

- A technical workshop with key-informants in Portugal.

In view of the exploratory nature of the research, and the current political sensitivity of the issue in Portugal, strategies were selected which would provide both a firm evidence base drawing on international experience, to inform and contextualize the focus in Portugal, but which would also start engaging the range of stakeholders in Portugal in order to begin to map out the scope for any policy dialogue in the future. More specific details of the methods used in the study are provided below, as part of the reporting of results for each of the six aspects of the study.

\section{Results}

\section{International comparison of nurse ratios}

One broad indicator of the availability of nursing staff is the nurse to population ratio. Annual data collated and published by the Organisation for Economic Co-operation and Development (OECD) gives a profile of the relative nurse to population ratio across the countries of the OECD, and some additional countries ${ }^{(15)}$. This comparison has to be undertaken with some caution because of differences in definition and methods of data collection but does prove some basis for analysis. OECD data (Figure 1) shows that there were about 9 practising nurses per 1000 population on average across OECD countries in 2009 . The number of nurses per capita was 
highest in some Nordic countries, with 14 to 15 nurses per 1000 population. Portugal, with a reported 5.6 nurses per 1000 population was notably lower than the OECD average.

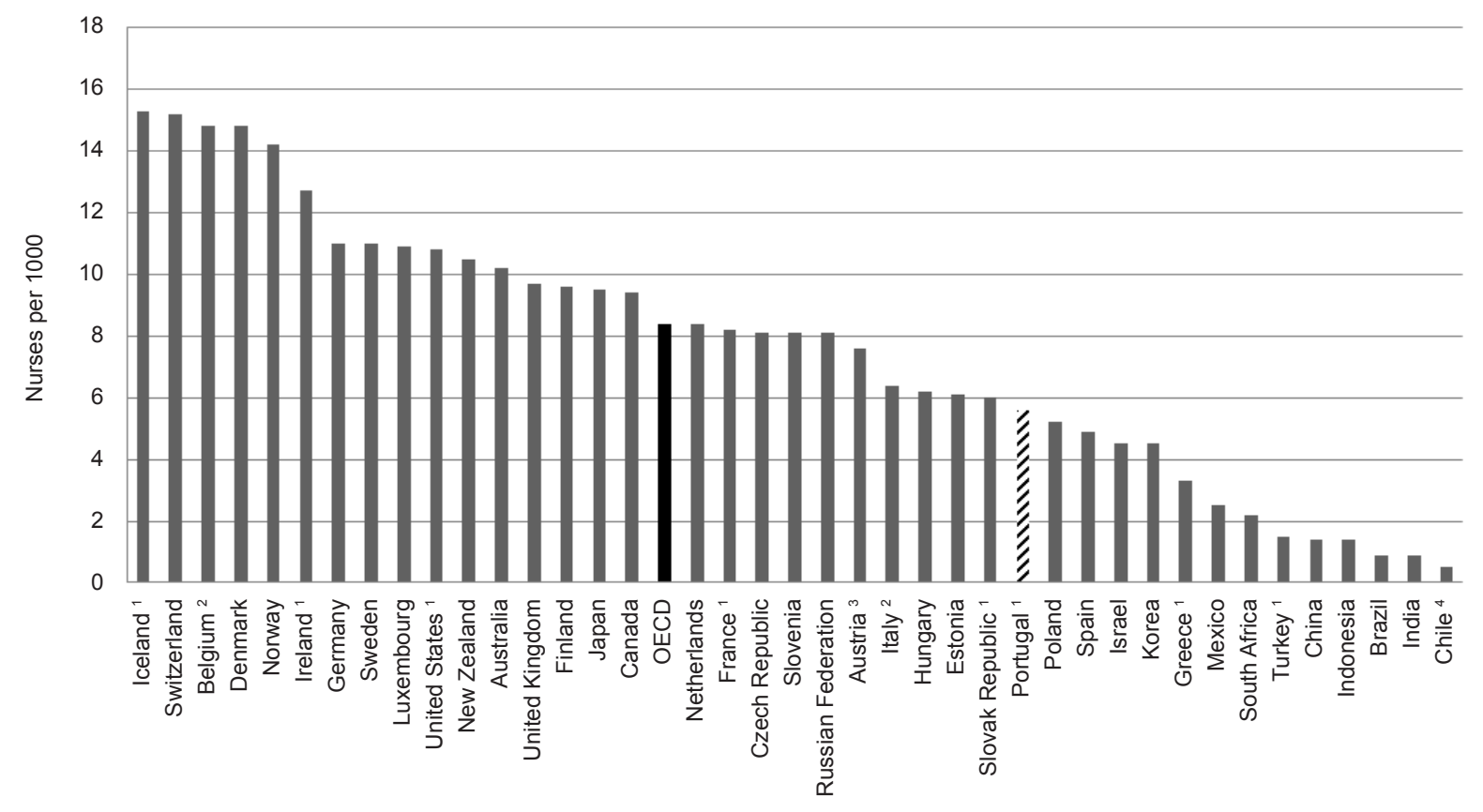

Source: OECD 2011; http://dx.doi.org/10.1787/888932524279

Figure 1 - Practising Nurses per 1000 population, selected countries, c2009

A second important indicator is the assess the relative availability of nurses and physicians who are working in the country. This gives some indication of the skill mix deployed in the health sector. OECD data is presented as an indicator of the number of nurses per physician. In 2009, the nurse-to-doctor ratio ranged from five nurses per doctor in Ireland to less than one nurse per doctor in Chile, Greece and Turkey (Figure 2 ). The average across OECD countries is just below three nurses per doctor. The number of nurses per doctor in Portugal is also relatively low, at 1.5 nurses per physician.

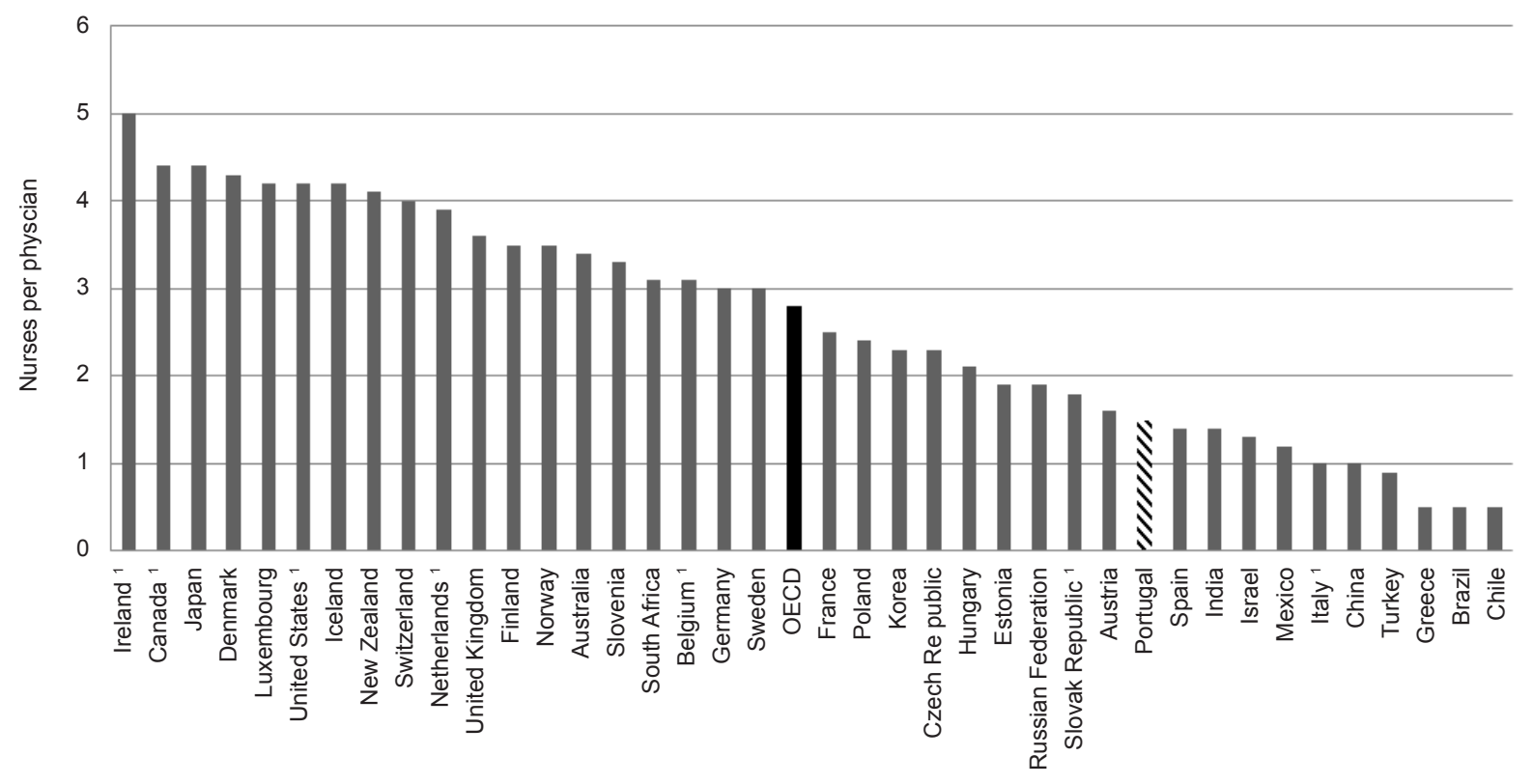

Source: OECD 2011: http://dx.doi.org/10.1787/888932524298

Figure 2 - Nurse: Physician ratio, OECD countries c2009 


\section{Document and media review: Portugal}

In order to provide more specific country context, an online, google search for documents on the topic of the expansion of the role of nurses in Portugal was conducted using the following key Portuguese words: combinação eficiente de profissionais de saúde, combinação de competências entre médicos e enfermeiros, alargamento de competências de enfermeiros, substituição de médicos por enfermeiros, prescrição por enfermeiros, vigilância da gravidez por enfermeiros. In parallel, daily and weekly Portuguese newspapers, journals, magazines were searched, also on Google, for the period between 1 January 2010 and 31 December 2011.

More than 4000 results, including articles in academic and professional journals, reports and electronic documents such as blogs and newsletters, of which only 17 were of detailed and direct relevant to the study, and were reviewed for reference to the issue of expansion of nurses' role and tasks.

Key documents identified in the search included a WHO report commissioned as part of the review of the National Health Plan(16) which concluded that "evidence shows that broadening the scope of professional practice for nurses, if carefully implemented, can be an efficient and cost-effective way to deal with demographic challenges (...) and can improve access and satisfaction of both patients and professionals"; a recent report from the Health Regulatory Agency in Portugal (Entidade Reguladora da Saúde- ERS) ${ }^{(5)}$ which noted that some categories of professionals, namely nurses and technicians may be underutilized, and which stated that some basic medical acts can safely be executed by adequately trained nurses and technicians; a background report on human resources for health, commissioned for the preparation of the new National Health Plan- 2011-2016(3) which stressed that "the low nurse/physician ratio indicates primarily a productivity and cost-effectiveness problem" and concluded that "there is scope for task shifting and delegation of tasks, particularly from physicians to nurses" ; and the recent report on "Reforming the hospital sector" commissioned by the Ministry of Health in Portugal(6), which explicitly recommended "the attribution of new activities to nurses" (p108), to avoid using physicians for tasks which do not require their level of expertise; and a review of the Portuguese health system which noted that "One of the major challenges for the next 10 years, not yet translated into policy actions, is the redefinition of roles for health care professionals"(17).
The search of media articles also showed that the topic of nurses in advanced roles has come increasingly to public attention in Portugal in recent times. Issues reported included various stakeholders stances on the possibility of legal changes to authorize nurses to prescribe medicines, broader issues related to health sector efficiency during the economic and financial crisis, and questions of the composition of the health workforce and of the distribution of roles among the various groups of professionals.

\section{Key informant interviews}

The second phase of the Portugal based assessment were 14 semi-structured face-to-face interviews, conducted between July and October of 2011 with keyinformants including representatives of medical and nursing councils, faculties and schools of medicine and nursing, hospital directors and professional associations. The main topics explored were $t$ scope of practice of physicians and nurse, limitations and difficulties with the existing skill mix between physicians and nurses, and impact, opportunities and threats, of implementing advanced nursing in Portugal. The main finding was that opinions of key stakeholders are still divided in Portugal and there does not appear to exist a strong advocacy movement in favour of changes in the physician- nurse skill mix.

\section{Survey of first line managers}

The key informant interviews were complemented by a survey of the opinions of first line managers of Groups of Health Centers (Agrupamentos de Centros de saúde- ACES). ACES were created in Portugal in 2009 with a mandate to improve coordination and efficiency of basic health services at local and sub-regional level through better planning and sharing of resources. There are 73 ACES, with a management structure consisting of an Executive Director, a Clinical Council (CC) and a Management Support Unit (UAG). The CC includes a family physician as president, a Public Health physician, a nurse and another health professional.

ACES Executive Directors and Clinical Council members were targeted because they are at the front line of the delivery of services and they are well positioned to assess the relevance or not of the expansion of nurse's roles in primary care, as well as its feasibility. A questionnaire of 10 closed (Likert scale) and two open questions was developed as an online survey. An email with the online survey link was sent to all the Executive Directors and members of Clinical Councils, using the 
mailing list of a training program to which the targeted population participated in 2009-2010 of 365 emails sent ( $5 \times 73$ Group of Health Centers), 49 rebounded for being inactive and 101 valid answers were collected, corresponding to a $32 \%$ response rate.

Key points emerging from the survey were that most respondents believed that discussion on advanced roles for nurses was relevant to the Portuguese context, and that there was specific scope for specific tasks to be undertaken by nurses. Most respondents (90\%) agreed that the discussion of the development of nursing advanced roles in Portugal, in order to improve accessibility of health services is relevant, most $(88 \%$ ) also agreed with the statement "Among the frequent tasks executed by physicians, there are some that could be executed by adequately trained nurses" (see Figure 3 )

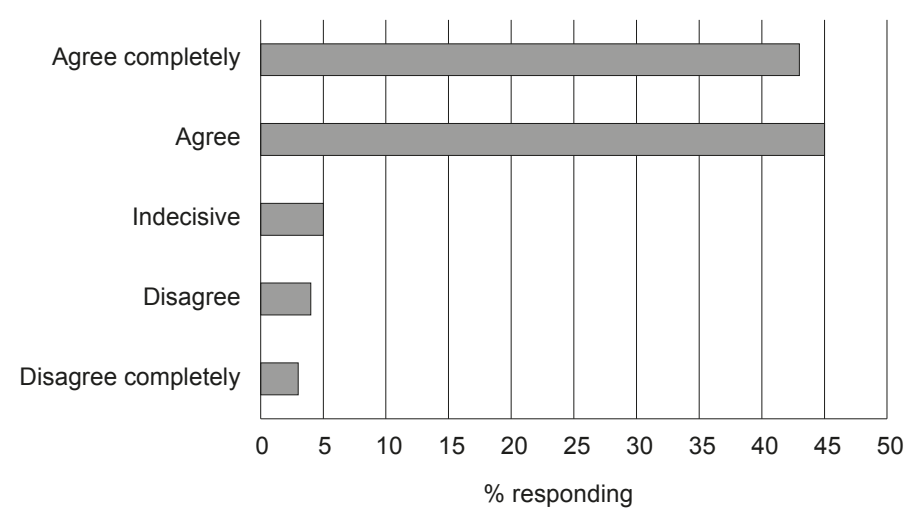

Source: ACES survey

Figure 3 - ACES response to question "Among the frequent tasks executed by physicians, some could be executed by trained nurses" $(n=101)$

A similar number agreed that the development of advance roles for nurses necessarily implies the introduction of specific training. Other key findings included that $85 \%$ of respondents considered that medical and nursing professional councils should have the last word on the expansion of nursing advanced roles, that $84 \%$ agreed that certification of competencies mechanisms would be needed and that $74 \%$ of respondents agreed that the opportunities created by the expansion of the roles of the nurses would compensate for any risks (see Figure 4).

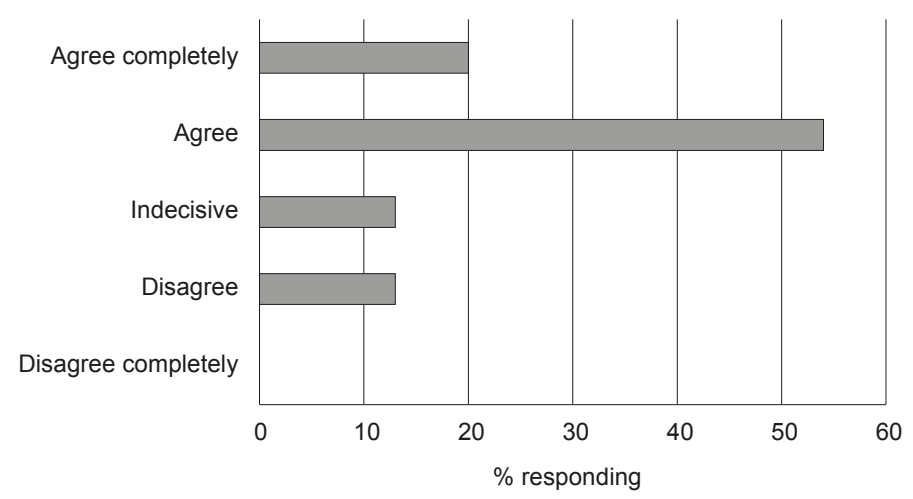

Source: ACES survey

Figure 4 - ACES response to question "The opportunities created by the expansion of the roles of nurses compensate for the risks" $n=101$ )

Primary care was seen by $68 \%$ of respondents as the appropriate field to start experimenting with advanced roles, and $57 \%$ agreed that the expansion of nurse's roles permitted the substitution of costly production inputs by less expensive ones (Figure 5). 


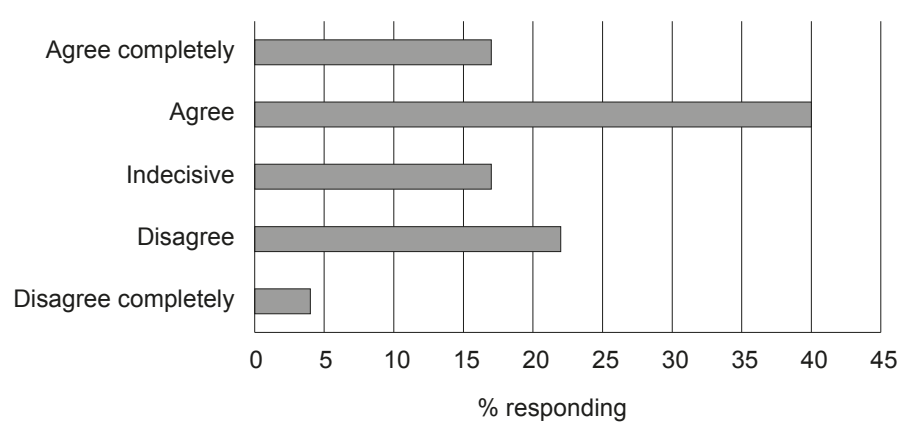

Source: ACES survey

Figure 5 - ACES response to question "The expansion of nurses' roles allows for the substitution of costly inputs by less costly inputs" $n=101$ )

In response to open questions, ACES survey participants mentioned the following areas where nurses' roles could be expanded: Integrated disease management, chronic disease and pregnancy management, care to vulnerable groups, diabetes, hypertension, screening and orientation in situations where medical care is not needed (application of normative decision flowcharts), maternal and child care, nutrition counseling, health promotion in general, treatment and evaluation of wounds, and suture of simple and superficial injuries. Regarding the authorization to write prescriptions, it was recognized as acceptable for specific complementary diagnosis exams, and for limited types of medicines (for example, analgesics, contraception and anti-tobacco, anti-pyretic in case of a high fever); one respondent stated that nurses should not only prescribe but also be authorized to make small adjustments of doses of medical prescriptions.

The survey responses highlighted that, although there is some acceptance of the potential for expanded roles for nurses amongst some of the medical profession, there are concerns with regard to patient safety and quality of care. The nursing curriculum would need adjustments and professional regulation would have to be adapted, which would require collaboration between the Medical and Nursing Councils. In addition, the absence of financial and organizational incentives for nurses to take up more complex functions is also a potential constraint. Some respondents considered that the organizational conditions for effective teamwork are not all in place, which limits the possibility of expanding nurses' roles. Another constraint identified was the absence of information systems that track the activities of each professional and of guidelines and protocols that ensure that everyone knows what the other members of the team are supposed to do and actually do. This is perceived as a prerequisite to building mutual trust and developing informed policy making, a critical condition for the acceptance of the expansion of roles of nurses, and eventually of other professionals.

\section{Workshop with key informants}

A technical workshop was organized on 10 February 2012 with the objective of obtaining initial responses from stakeholders, to the preliminary results of the study. The meeting was held under "Chatham House", whereby a report of the meeting was written, but all discussion was non attributable. There were 19 participants including managers of health services, officials of nursing and medical councils, and researchers. Much of the discussion concerned the contents of any expansion of roles of nurses. This question reflects on what would be the most appropriate skills-mix in health services to guarantee the quality of services and to better respond to demand, namely in terms of more efficient utilization of existing resources. It was argued that this discussion should take into account the specificities of the Portuguese health sector, e.g. how services are organized and financed. It was also deemed important to ensure that expanding the roles of nurses or of any other group would not have collateral negative effects on other professional groups.

Regarding the feasibility of expanding nurses' roles at present in Portugal, the consensus was that "the road is still long" before this may become fully possible. Among nurses and physicians there are very differing views, with some much in favor and others much against and all sorts of nuances in between. However there was a clearer consensus in saying that the current economic and financial crisis offered an opportunity to open the discussion on how services are delivered and how professionals can be used more efficiently. One 
important obstacle was mentioned, that of the current relatively low nurse: physician ratio in Portugal which makes it difficult to convince nurses to accept new responsibilities in addition to an already heavy workload.

The issue of the potential for nurses to have the right to prescribe was the most hotly debated. The consensus was that this needed to be regulated and that in principle, nurses should be able to prescribe medicines and order examinations and tests in the areas in which they are authorized to practice. All assumed that training would have to be adjusted in accordance to the knowledge requirements of these new activities.

Finally, participants remarked that using evidence on successful international experiences was helpful, but that it was insufficient in itself. Evidence from national research in Portugal, which is in rather short supply at present, was also needed.

The workshop showed that there was a need for clarification of the language used to discuss role expansion. Terms such as substitution, delegation, teams of peers, complementarity, role, tasks, competencies, scope of practice, come in the discussion, but they are not always used to describe the same issue, or understood in the same manner by all.

To add to the confusion, there is no clear and operational definition of what is a medical task or a nursing task in the Portuguese legislation. Participants added that at ground level, professionals themselves had no clear understanding of what "belonged" to each professional group. Without such definitions, it may be more difficult to be precise about the contents of an expanded role, or which tasks could be delegated.

\section{Discussion}

\section{The policy context for nurses in advanced roles}

The international review had highlighted that different countries are at different stages of development in terms of their use of nurses in advanced roles. The various elements of the study conducted in Portugal showed that there is no clear consensus on if, or how, any developments in advanced roles for nurses should be taken forward in the country. In this regard, the history of the introduction of nurse practitioners in the USA is of relevance. US was one of the first countries to develop such roles, almost 50 years ago. This chronology highlights the significance in the US of government funding as "pump priming" in the 1960s and 1970s, and the ongoing process of gaining legislative support through the $1970 s, 1980$ s and $1990 s^{(18)}$. Different countries will have different timetables and drivers. The key points that any country should consider in looking at the potential for using nurses in advanced roles will have to include(7):

First, there is a need for stakeholders to agree on the need for advanced practice nurses. Key stakeholders will include representatives of the nursing and medical professions, ministries of health and education, employers and regulators. Several commentators noted the need to base this approach on mutual respect, and on developing a collaborative model of health care delivery

Second, where principles of need have been agreed, there is then a requirement to ensure that the advanced role(s) have been defined, and the associated educational requirements have been identified.

Third, issues of certification and regulation have to be determined. As summarised in this report, different countries have adopted different approaches. Some have developed a single national level approach to certification/licensure with separate national registration, whilst others have adopted a voluntary approach.

Fourth, the career structure and payment system for advanced nurses has to be established, and the potential impacts on other professions, the organization and accessibility of services has to be assessed.

Portugal is at the first stage of this possible process. As described in this report, there is a limited evidence base in the country about the potential impact of developing nurses in advanced roles. However, well documented international experience shows that this can be done effectively, whilst maintaining quality of care and with benefits for them and for providers as well.

\section{Conclusion}

The limited evidence base on nurses in advanced roles in Portugal is a constraint on progress, but it is not an excuse for inaction. Further research in Portugal which looks at local experience with deploying health professionals in innovative and effective roles would assist in informing policy direction. Most importantly, there is the need to move forward with a fully informed policy dialogue, taking account of the current political, economic and health service realities of Portugal, which can explore in a structured and objective manner what is best for healthcare in the country, in terms of the overall health workforce profile.

\section{References}

1. World Health Organization Europe (WHO). [Internet]. WHO Evaluation of the National Health Plan of Portugal 
(2004-2010). 2010. [acesso 20 jun 2012]; Lisbon: World Health Organization Europe, Ministério da Saúde, Alto Comissariado da Saúde; 2010. Disponível em: http:// www.acs.min-saude.pt/pns2012-2016/files/2010/02/ WHO-E.pdf

2. European Federation of Nurses Associations (EFN) (BE).Caring in Crisis: The Impact of he Financial Crisis on Nursing and Nurses: A Comparative Overview of 34 Countries. 2012. EFN. Brussels; 2012.

3. Dussault G, Fronteira I. Human resources for health (HRH) plan component of national health plan 201115 (Portugal). 2010. [acesso 20 jun 2012]; Lisbon: Ministério da Saúde, Alto Comissariado da Saúde; 2010. Disponível em: http://www.acs.min-saude.pt/pns20122016/files/2010/08/RHS2.pdf

4. Barros PP. Substitution at the margin: physicians vs nurses. 2011 Presentation to 12th National Conference on Health Economics, Lisbon, 13-15 October. [acesso 20 junh 2012]; Disponível em: http://12cnes.apes.pt/

5. Entitade Reguladora da Saúde (PT). Análise da sustentabilidade financeira do Serviço Nacional de Saúde. Porto; 2011. [acesso 20 jun 2012]; Disponível em: http://www. ers.pt/

6. Grupo da Reforma Hospitalar (PT). Relatório Final do Grupo Técnico para a Reforma Hospitalar. 2011. [acesso 20 jun 2012]; Lisbon; 2011. Disponível em: http://www. portaldasaude.pt/NR/rdonlyres/84FCFCE2-3C84-4ABE8E5F-AD4DDB0B46F4/0/RelatorioGTRH_Nov2011.pdf

7. Buchan J, Calman L. Skill Mix and Policy Change in the Health Workforce: Nurses in Advanced Roles. OECD Health Working Papers no. 17. Paris: OECD; 2004.

8. Delamaire M, Lafortune, G. Nurses in Advanced Roles: A Description and Evaluation in 12 Developed Countries. OECD Health Working Papers no.54. Paris: OECD; 2010. 9. International Council of Nurses (ICN). Definitions and Characteristics of the Role. 2011. [acesso 20 junh 2012]; Geneva: ICN; 2011. Disponível em: http://66.219.50.180/inp\%20apn\%20network/ practice $\% 20$ issues/role\%20definitions.asp

10. Pulcini JM, Jelic RGul,Yuen L A. An international survey on advanced practice nursing, education, practice and regulation. Image: J Nurs Scholars. 2010;42(1):31-9.

11. Laurant M, Reeves D, Hermens R, Braspenning J, Grol R, Sibbald B.. Substitution of doctors by nurses in primary care. Cochrane Database of Systematic Reviews 2005, Issue 2, Art. No.: CD001271. DOI: 10.1002/14651858.CD001271.pub2.

12. Chan D, Harris S, Roderick P, Brown D, Patel P. A randomised controlled trial of structured nurse- led outpatient clinic follow-up for dyspeptic patients after direct access gastroscopy. BMC Gastroenterol. 2009;9:12.

13. Voogdt-Pruis HR, BeusmansGHMI, Gorgels APM, Kester ADM, Van Ree JW. Effectiveness of nurse-delivered cardiovascular risk management in primary care: a randomised trial. Br J Gen Practice. 2010;60(570):40-6. 14. Chen C, McNeese-Smith D, Cowan M, Upenieks $\mathrm{V}$, Afifi A. Evaluation of a nurse practitioner-led care management model in reducing inpatient drug utilization and cost. Nurs Econom. 2009;27(3):160-8.

15. Organisation for Economic Cooperation and Development (2011) Health at a Glance 2011:OECD Indicators. [acesso 20 jun 2012]; Paris (FR): OECD Publishing; 2011. Disponível em: http://www.oecd.org/ dataoecd/6/28/49105858.pdf

16. World Health Organization Europe (WHO). Portugal Health System Performance Assessment. 2009. Lisbon: World Health Organization Regional Office for Europe, Ministério da Saúde, Alto Comissariado da Saúde; 2009. 17. Barros PP, Simões JM. Portugal Health System Review, 2011. European Observatory of Health Systems and Policy. Health Systems in Transition, 13;4 Portugal Health System Review, Brussels; [acesso 20 jun 2012]; Disponível em: http://www.euro.who.int/_data/ assets/pdf_file/0019/150463/e95712.pdf

18. Pulcini J, Wagner M. Nurse practitioner education in the United States: A success story. Clin Excellence Nurse Practit. 2002;6(2):51-6. 